\title{
Insulinomimetic Zn(II) Complexes as Evaluated by Both Glucose-Uptake Activity and Inhibition of Free Fatty Acids Release in Isolated Rat Adipocytes
}

\author{
Midori Nishide, ${ }^{a}$ Yutaka Yoshikawa, ${ }^{b}$ Eriko U. Yoshikawa, ${ }^{a}$ Kinuyo Matsumoto, ${ }^{a}$ \\ Hiromu SAKURAI, ${ }^{b}$ and Naemi M. KAJIWARA ${ }^{*, a}$ \\ ${ }^{a}$ Laboratory of Nutrition Physiology, Graduate School of Life Science, Kobe Women's University; 2-1 Aoyama, Suma, \\ Kobe 654-8585, Japan: and ${ }^{b}$ Department of Analytical and Bioinorganic Chemistry, Kyoto Pharmaceutical University; 5 \\ Nakauchi-cho, Misasagi, Yamashina-ku, Kyoto 607-8414, Japan. \\ Received March 18, 2008; accepted May 13, 2008; published online May 21, 2008
}

We prepared 4 new $\mathrm{Zn}(\mathrm{II})$ complexes with $\mathrm{Zn}\left(\mathrm{O}_{4}\right), \mathrm{Zn}\left(\mathrm{N}_{2} \mathrm{O}_{2}\right)$, and $\mathrm{Zn}\left(\mathrm{S}_{2} \mathrm{O}_{2}\right)$ coordination modes and evaluated their insulinomimetic activities in an in vitro study. The insulinomimetic activities of bis(pyrrole-2-carboxylato)zinc $\left(\mathrm{Zn}(\mathrm{pc})_{2}\right)$, bis $\left(\alpha\right.$-furonic acidato)zinc $\left(\mathrm{Zn}(\mathrm{fa})_{2}\right)$, bis(thiophene-2-carboxylato)zinc $\left(\mathrm{Zn}(\mathrm{tc})_{2}\right)$, and bis(thiophene-2-acetato)zinc $\left(\mathrm{Zn}(\mathrm{ta})_{2}\right)$ complexes were found to be higher than that of zinc sulfate $\left(\mathrm{ZnSO}_{4}\right) . \mathrm{Zn}(\mathrm{ta})_{2}$ showed the highest insulinomimetic activity among the $\mathrm{Zn}$ (II) complexes because of its high lipophilicity.

Key words $\mathrm{Zn}(\mathrm{II})$ complex; insulinomimetic activity; inhibition of free fatty acid-release; glucose-uptake activity

Diabetes mellitus (DM) is emerging as one of the most significant diseases of the 21 st century with the worldwide increase in the number of patients suffering from this disease. $^{1-3)}$ According to the 2002 report of the Ministry of Health, Labor and Welfare of Japan, the number of people in Japan at "a high risk of developing diabetes" (glycosylated hemoglobin $\left[\mathrm{HbA}_{1 \mathrm{c}}\right]$ higher than $6.1 \%$ or receiving treatment for DM) has increased from 6900000 to 7400000 over 5 years. ${ }^{4)}$ In addition, the number of people with "the possibility of developing DM" $\left(\mathrm{HbA}_{1 \mathrm{c}}\right.$ in the range of $5.6-6.1 \%$ and receiving no treatment for $\mathrm{DM}$ ) has also increased from 13700000 in 1997 to $16200000 .{ }^{4)}$ On the other hand, no agents other than insulin have been developed for the treatment of either type $1 \mathrm{DM}$ or severe type $2 \mathrm{DM}$. Therefore, there is an urgent need for developing new types of therapeutic agents for the treatment of DM. Several researchers have attempted to confirm the insulinomimetic activity of the $\mathrm{Zn}^{2+}$ ion. ${ }^{5,6)}$ We focused on the finding that $\mathrm{Zn}$ (II) complex bound to sulfur showed a strong insulinomimetic activity and a blood glucose lowering effect. ${ }^{7,8)}$ In this study, we synthesized the $\mathrm{Zn}(\mathrm{II})$ complexes with the $\mathrm{Zn}\left(\mathrm{S}_{2} \mathrm{O}_{2}\right)$ coordination mode by using thiophene carboxylic acid or thiophene acetic acid, both of which contain thiophene as the basic skeleton, and $\mathrm{Zn}(\mathrm{II})$ complexes with furan or pyrrole wherein nitrogen of pyrrole or oxygen of furan was substituted for sulfur of thiophene carboxylic acid. We measured the insulinomimetic activity and investigated the correlation between their activities and lipophilicity.

\section{Experimental}

Materials All reagents and solvents used in this study were of the highest commercially available grade and were used as obtained. D-(+)-Glucose, $\mathrm{ZnSO}_{4}$, thiophene-2-carboxylic acid, pyrrole-2-carboxylic acid, and $\alpha$-furoic acid were purchased from Wako Pure Chemical Co. (Osaka, Japan); thiophene-2-acetic acid was obtained from Tokyo Kasei Inc. (Tokyo, Japan); and $( \pm)$-epinephrine hydrochloride, collagenase, and bovine serum albumin (BSA; fraction V) were purchased from Sigma Chemical Co., (St. Louis, MO, U.S.A.).

Synthesis of $4 \mathrm{Zn}$ (II) Complexes The intended $\mathrm{Zn}$ (II) complexes were readily prepared by adding $\mathrm{ZnSO}_{4} \cdot 7 \mathrm{H}_{2} \mathrm{O}$ and barium hydroxide to an aqueous solution of various ligands at room temperature. ${ }^{9,10)}$ The $\mathrm{Zn}$ (II) complexes were purified with hot water to obtain bis(thiophene- 2-carboxylato $)$ zinc $\left(\mathrm{Zn}(\mathrm{tc})_{2}\right)$, with 2-propanol to obtain bis $(\alpha$-furoic acidato)zinc $\left(\mathrm{Zn}(\mathrm{fa})_{2}\right)$, and with methyl alcohol to obtain bis(thiophene-2-acetato)zinc $\left(\mathrm{Zn}(\mathrm{ta})_{2}\right)$ and bis(pyrrole-2-carboxylato)zinc $\left(\mathrm{Zn}(\mathrm{pc})_{2}\right)$.

Inhibitory Effects of the Zn(II) Complexes on Free Fatty Acid (FFA) Release and Glucose Uptake Enhancing Ability in Isolated Rat Adipocytes Treated with Epinephrine Male Wistar rats (age, 7-8weeks; weight, 200-250 g) were obtained from CLEA Japan Inc., (Japan). The animals were maintained in a 12-h light/dark cycle in our central animal facility, and they were given free access to solid food (CE-2: CLEA Japan Inc.) and tap water. The animal experiments were approved by the Experimental Animal Research Committee of Kobe Women's University (KWU) and were performed according to the Guidelines for Animal Experimentation of KWU. In order to evaluate the in vitro insulinomimetic activity of the $\mathrm{Zn}$ (II) complexes, we first performed a simple and convenient in vitro assay based on the inhibition of FFA (Free Fatty Acids) release from isolated rat adipocytes treated with epinephrine (adrenaline). ${ }^{11)}$ This assay has been used by many researchers over 10 years. ${ }^{12-14)}$ The glucose-uptake enhancing ability of the $\mathrm{Zn}$ (II) compounds was evaluated based on the decrease in the glucose concentrations in the medium; the following equation was used: glucose-uptake level $=C_{\text {control }}-C_{\text {compound }}(\mu \mathrm{mol} / \mathrm{ml})$, where $C_{\text {control }}$ is the glucose concentration in the medium containing cells without compounds such as the $\mathrm{Zn}(\mathrm{II})$ compounds after incubation time,${ }^{15)}$ and $C_{\text {compound }}$ is the residual glucose concentration in the medium containing cells treated with these compounds after incubation time. The glucose-uptake ability of the compounds was evaluated by the apparent $\mathrm{EC}_{50}$ values, that is, the $50 \%$ enhancing concentration of the compound with respect to the maximal glucose-uptake concentration during the 3 -h incubation. These complexes were confirmed to have dose-dependent concentrations of $5 \times 10^{-4}, 4 \times 10^{-4}, 3 \times 10^{-4}$, $2 \times 10^{-4}$, and $10^{-3} \mathrm{M}$. Furthermore, the inhibitory activity of the compounds on FFA release from isolated rat adipocytes treated with epinephrine was evaluated with respect to the $\mathrm{IC}_{50}$ values, that is, the $50 \%$ inhibitory concentration of the compound with respect to the FFA release during the 3-h incubation. The assay confirmed the dose-dependent concentrations of the tested compounds: $10^{-4}$ and $5 \times 10^{-4}, 10^{-3} \mathrm{M}$ for the $\mathrm{Zn}$ (II) complexes and $10^{-4}$, $5 \times 10^{-4}$, and $7 \times 10^{-4} \mathrm{M}_{\text {for }} \mathrm{ZnSO}_{4}$

Measurement of Partition Coefficients of the Zn(II) Complexes The partition coefficients $(\log \mathrm{P})$ of the $\mathrm{Zn}$ (II) complexes were determined by the conventional method with the 10 mM HEPES buffer ( $\mathrm{pH} 7.4) / n$-octanol system. After shaking the mixture for $1 \mathrm{~h}$ at $37^{\circ} \mathrm{C}$, it was centrifuged at $8000 \mathrm{rpm}$ for $10 \mathrm{~min}$. The 2 resulting phases were separated. The $\mathrm{Zn}(\mathrm{II})$ concentration in each phase was measured at the characteristic wavelength of approximately $232-256 \mathrm{~nm}$ due to the aromatic ring.

Statistical Analysis The data are expressed as mean \pm S.D. The differences between the groups were tested by a one-way ANOVA followed by Tukey's multiple-comparison post hoc test. Pairwise associations were examined by Pearson's correlation coefficient test. 
Table 1. Physicochemical Properties and Insulinomimetic Activities of $\mathrm{Zn}$ (II) Complexes

\begin{tabular}{|c|c|c|c|c|c|c|c|}
\hline \multirow[t]{2}{*}{ Complexes } & \multicolumn{3}{|c|}{$\begin{array}{l}\text { Elemental Analysis } \\
\text { Found/Calcd. }\end{array}$} & \multirow{2}{*}{$\begin{array}{c}\text { IR spectra } \\
\text { for } v_{\mathrm{C}=\mathrm{O}} \\
\text { (ligand) } / \mathrm{cm}^{-1}\end{array}$} & \multirow{2}{*}{$\begin{array}{c}\mathrm{IC}_{50} \text { value } \\
(\mu \mathrm{M})\end{array}$} & \multirow{2}{*}{$\begin{array}{c}\mathrm{EC}_{50} \text { value } \\
(\mu \mathrm{M})\end{array}$} & \multirow[t]{2}{*}{$\log P$} \\
\hline & $\mathrm{C} / \%$ & $\mathrm{H} / \%$ & $\mathrm{~N} / \%$ & & & & \\
\hline $\mathrm{ZnSO}_{4}$ & - & - & - & - & $280 \pm 20$ & $250 \pm 10$ & - \\
\hline $\mathrm{Zn}(\mathrm{tc})_{2}$ & $\begin{array}{l}37.83 \\
37.57\end{array}$ & $\begin{array}{l}2.02 \\
1.89\end{array}$ & & $\begin{array}{l}1615 \\
(1684)\end{array}$ & $270 \pm 20$ & $150 \pm 10^{a)}$ & -1.61 \\
\hline $\mathrm{Zn}(\mathrm{ta})_{2}$ & $\begin{array}{l}41.73 \\
41.45\end{array}$ & $\begin{array}{l}2.95 \\
2.90\end{array}$ & & $\begin{array}{l}1559 \\
(1705)\end{array}$ & $260 \pm 20$ & $120 \pm 10^{a)}$ & -1.55 \\
\hline $\mathrm{Zn}(\mathrm{fa})_{2}$ & $\begin{array}{l}41.51 \\
41.77\end{array}$ & $\begin{array}{l}2.31 \\
2.10\end{array}$ & & $\begin{array}{c}1620 \\
(1686)\end{array}$ & $310 \pm 50$ & $230 \pm 10$ & -2.23 \\
\hline $\mathrm{Zn}(\mathrm{pc})_{2}$ & $\begin{array}{l}36.60 \\
36.35\end{array}$ & $\begin{array}{l}3.64 \\
3.42\end{array}$ & $\begin{array}{l}8.49 \\
8.48\end{array}$ & $\begin{array}{l}1561 \\
(1663)\end{array}$ & $280 \pm 20$ & $\left.190 \pm 20^{a}\right)$ & -1.76 \\
\hline
\end{tabular}

Data are expressed as means \pm S.D. for 3 experiments. a) Significance at $p<0.05 v s$. $\mathrm{ZnSO}_{4}$.

\section{Results and Discussion}

Structural Characteristics The Zn(II) complexes were characterized by several physicochemical methods, as summarized in Table 1. For the elemental analysis, both the calculated and empirical values of the percent concentrations of $\mathrm{C}, \mathrm{H}$, and $\mathrm{N}$ were identical within the estimated range of experimental error. In the IR spectra, the frequency of the $v_{\mathrm{C}=\mathrm{O}}$ band of the complex shifted with respect to that of the free ligand. These results suggest that the binding ratio of the $\mathrm{Zn}$ (II) complexes with the Zn(II) ligand was $1: 2$ (Fig. 1).

In Vitro Insulinomimetic Activity of the $4 \mathrm{Zn}$ (II) Complexes The FFA release inhibitory activity $\left(\mathrm{IC}_{50}\right.$ values) and the glucose-uptake activity $\left(\mathrm{EC}_{50}\right.$ values $)$ were calculated from the experimental data (Table 1 ). The $\mathrm{IC}_{50}$ values indicated that $\mathrm{Zn}(\mathrm{tc})_{2}$ and $\mathrm{Zn}(\mathrm{ta})_{2}$ with the $\mathrm{Zn}\left(\mathrm{S}_{2} \mathrm{O}_{2}\right)$ coordination mode had higher insulinomimetic activities than $\mathrm{Zn}(\mathrm{fa})_{2}$ with the $\mathrm{Zn}\left(\mathrm{O}_{4}\right)$ coordination mode and $\mathrm{Zn}(\mathrm{pc})_{2}$ with the $\mathrm{Zn}\left(\mathrm{N}_{2} \mathrm{O}_{2}\right)$ coordination mode. Moreover, $\mathrm{Zn}(\mathrm{ta})_{2}$ exhibited a higher potent insulinomimetic activity than $\mathrm{Zn}(\mathrm{tc})_{2}$ with the same coordination mode. The $\mathrm{EC}_{50}$ values of $\mathrm{Zn}$ (II) complexes $\left(\mathrm{Zn}(\mathrm{tc})_{2}=150, \mathrm{Zn}(\mathrm{ta})_{2}=120, \mathrm{Zn}(\mathrm{fa})_{2}=230\right.$, and $\left.\mathrm{Zn}(\mathrm{pc})_{2}=190 \mu \mathrm{M}\right)$ were significantly lower than those of $\mathrm{ZnSO}_{4}(250 \mu \mathrm{M})$. Especially, $\mathrm{Zn}(\mathrm{ta})_{2}$ with $\mathrm{Zn}\left(\mathrm{S}_{2} \mathrm{O}_{2}\right)$ coordination mode indicated not only the highest $\mathrm{IC}_{50}$ value but also the highest $\mathrm{EC}_{50}$ value. The partition coefficients $\left(C_{n \text {-octanol }} / C_{\text {buffer }}\right)$ of the $\mathrm{Zn}$ (II) complexes were measured with UV spectrophotometry. Many researchers have previously reported that a simple diffusion is important for transport through the membrane. ${ }^{16.17)}$ Moreover, it is believed that the action sites of $\mathrm{Zn}$ (II) are thought to be primarily located in the cells. ${ }^{18)}$ The high lipophilicity is thus the most important factor for transport through the membrane. The lipophilicity of $\mathrm{Zn}(\mathrm{ta})_{2}$ was the highest among all the $4 \mathrm{Zn}$ (II) complexes (Table 1). Interestingly, a good linear correlation was observed between $\mathrm{IC}_{50}$ or $\mathrm{EC}_{50}$ and the partition coefficients $(\log \mathrm{P})$ of the $\mathrm{Zn}$ (II) complexes (Fig. 2): we found that when the $\mathrm{Zn}$ (II) complexes have higher lipophilicity, the insulinomimetic activity will show the highest values. It is considered that $\mathrm{Zn}(\mathrm{ta})_{2}$ with the $\mathrm{Zn}\left(\mathrm{S}_{2} \mathrm{O}_{2}\right)$ coordination mode that exhibited a high lipophilicity, accelerated the cellular uptake and consequently, the complex showed the highest FFA release inhibitory activity and glucose-uptake effect among the $4 \mathrm{Zn}$ (II) complexes. In conclusion, we developed new, potent insulinomimetic $\mathrm{Zn}$ (II) complexes with the $\mathrm{Zn}\left(\mathrm{S}_{2} \mathrm{O}_{2}\right)$ coordination mode, and $\mathrm{Zn}(\mathrm{ta})_{2}$ showed the most highest insuli-

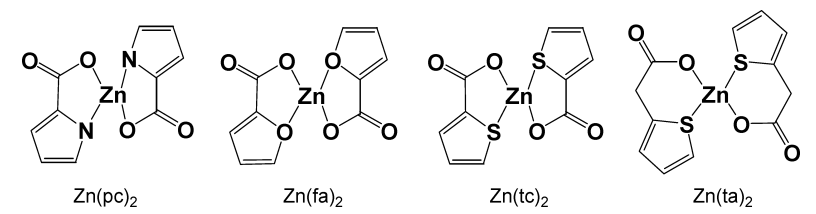

Fig. 1. Proposed Structure of $\mathrm{Zn}$ (II) Complexes
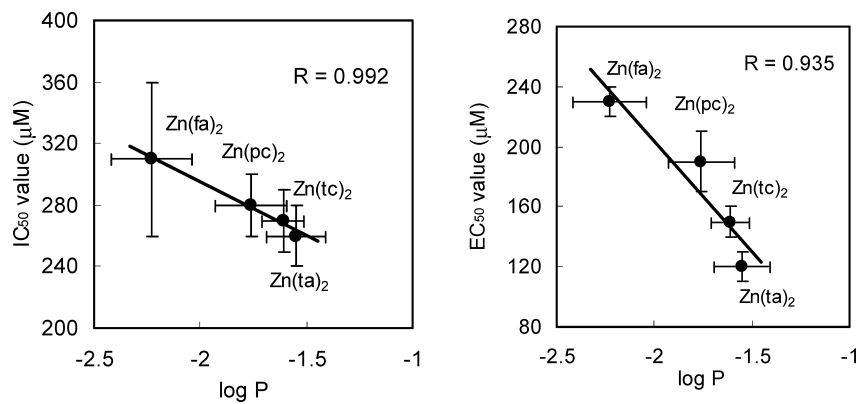

Fig. 2. Correlation between the $\mathrm{IC}_{50}$ or $\mathrm{EC}_{50}$ Values and Partition Coefficient $(\log \mathrm{P})$

$\mathrm{The} \mathrm{IC}_{50}$ values on FFA-release from isolated rat adipocytes treated with epinephrine and $\mathrm{EC}_{50}$ values on glucose-uptake. The $\log \mathrm{P}\left(C_{n \text {-octanol }} / C_{\text {buffer }}\right)$ of the $\mathrm{Zn}(\mathrm{II})$ complexes were measured by using UV spectrophotometory.

nomimetic activity among all other $\mathrm{Zn}$ (II) complexes. The effectiveness of this complex in diabetic animals will be reported in the near future.

Acknowledgments This study was supported in part by grants from Kobe Women's University (Grant-in Aids for Scientific Research), and partly by grants from the Ministry of Education, Culture, Sports, Science and Technology of the Japanese Government (Grant-in-Aids for Scientific Research, Scientific Research on Priority Areas, and Specially Promoted Research to H.S.).

\section{References}

1) Wild S., Roglic G., Sicree R., Green A., King H., "Global Burden of Disease," WHO, Geneva, 2003.

2) DeFronzo R. A., Bonadonna R. C., Ferrannini E., Diabetes Care, 15 318-368 (1992).

3) Vinik A., Pittenger G., Rafaeloff R., Rosenberg L., Duguid W., Diabetes Rev., 4, 235-263 (1996).

4) Survey on diabetes published recently, "Ministry of Health, Labor and Welfare," Japan, 2002.

5) James M. M., Charles S. C., J. Biol. Chem., 257, 4362 (1982).

6) Shisheva A., Gefel D., Schechter Y., Diabetes, 41, 982 (1992).

7) Adachi Y., Yoshida J., Kodera Y., Sakurai H., Chem. Lett., 34, 656 657 (2005).

8) Yoshikawa Y., Adachi Y., Sakurai H., Life Sci., 80, 759-766 (2007).

9) Yoshikawa Y., Ueda E., Kawabe K., Miyake H., Sakurai H., Kojima Y., 
Chem. Lett., 2000, 874-875 (2000).

10) Yoshikawa Y., Ueda E., Suzuki Y., Yanagihara N., Sakurai H., Kojima Y., Chem. Pharm. Bull., 49, 652-654 (2001).

11) Nakai M., Watanabe H., Fujiwara C., Kakegawa H., Satoh T., Takada J., Matsushita R., Sakurai H., Biol. Pharm. Bull., 18, 719-725 (1995).

12) Kiss E., Kawabe K., Tamura A., Jakusch T., Sakurai H., Kiss T., J. Inorg. Biochem., 95, 69-76 (2003).

13) Rangel M., Tamura A., Fukushima C., Sakurai H., J. Biol. Inorg. Chem., 6, 128-132 (2001).
14) Nakai M., Sekiguchi F., Obata M., Ohtsuki C., Adachi Y., Sakurai H., Orvig C., Rehder D., Yano S., J. Inorg. Biochem., 99, 1275-1282 (2005).

15) Adachi Y., Sakurai H., Chem. Pharm. Bull., 52, 428- 433 (2004).

16) Hamilton J. A., Prostaglandins Leukot. Essent. Fatty Acids, 60, 291297 (1999).

17) Zakim D., Proc. Soc. Exp. Biol. Med., 212, 5-14 (1996).

18) Yoshikawa Y., Ueda E., Kojima Y., Sakurai H., Life Sci., 75, 741-751 (2004). 